\title{
PENGARUH MODEL LEARNING CYCLE 7E TERHADAP HASIL BELAJAR FISIKA SISWA KELAS XI SMAN 8 MATARAM
}

\author{
Eti Sulastri*, Hikmawati, I Wayan Gunada \\ Program Studi Pendidikan Fisika, Universitas Mataram \\ *Email: etisulastri20@gmail.com
}

\begin{abstract}
This study aims to determine the effect of learning cycle $7 E$ model on physics learning outcomes of students of class XI SMAN 8 Mataram. The type of this research is experimental research with pretest-posttest control group design. The population in this study is all students of class XI SMAN 8 Mataram academic year 2017/2018. Sampling was done by purposive sampling technique, with class XI MIA 1 students as experiment class and XI MIA 2 class student as control class. The instruments used are multiple choice test and observation sheet. Based on the result of research, the average value for pretest of experiment class and control class is 26,783 and 28,333 while for the average of post-test of experiment class and control class is 60,696 and 52,667. The research hypothesis was tested by t-test with a significant level of 5\%. Data of learning result analyzed by using t-test of two parties obtained taccount equal to 2,071 and table equal to 1,679 at $d f=45$. According to the criteria of the hypothesis test, if $t_{\text {account }}$ greater than $t_{\text {table, then }} \mathrm{Ho}$ is rejected and Ha accepted. So it can be concluded that there is influence of Learning Cycle 7E model to physics learning result of class XI SMAN 8 Mataram.
\end{abstract}

Keywords: learning cycle 7E, learning outcomes.

\section{PENDAHULUAN}

Pesatnya perkembangan ilmu pengetahuan dan teknologi dan pendidikan sangat penting dan tidak dapat dipisahkan dari kehidupan. Maju mundurnya perkembangan suatu bangsa juga ditentukan oleh maju mundurnya pendidikan bangsa itu. Oleh karena itu mengingat pentingnya pendidikan maka pendidikan harus diperhatikan dan dilaksanakan dengan sebaik-baiknya.

Terlihat betapa pentingnya upaya menyelaraskan mutu pendidikan dengan tuntutan penguasaan ilmu pengetahuan dan teknologi. Sebab, sikap dan kemampuan seperti yang di sebutkan di atas tentu tidak bisa hadir begitu saja. melainkan harus ditumbuhkan secara bertahap dan terencana melalui pendidikan yang berkualitas.

Fisika merupakan salah satu cabang IPA yang mengkaji tentang berbagai fenomena alam dan memegang peranan yang sangat penting dalam perkembangan sains dan teknologi. Fisika dipandang sebagai dasar bagi pembangunan ilmu dan teknologi karena melalui belajar fisika dapat dibentuk pola berfikir ilmiah sehingga mata pelajaran fisika sangat diperlukan untuk dipelajari di sekolah. Berdasarkan observasi, menunjukkan bahwa pelajaran fisika masih kurang diminati oleh siswa, sehingga sebagian besar siswa belum mampu mencapai kompetensi yang diinginkan. Hal ini dikarenakan pembelajaran fisika lebih cenderung menempatkan ilmu fisika sebagai sejumlah informasi yang harus disampaikan dan dihafalkan. Dalam proses pembelajaran, siswa hanya mendengarkan saja dan kurang mengikutsertakan siswa dalam menyelidiki hal-hal baru seperti melakukann beberapa percobaan.

Selain itu, penerapan pembelajaran fisika masih kurang dilakukan sehingga siswa tidak tahu manfaat dan penerapan fisika dalam kehidupan sehari-hari. Jika hal ini dibiarkan terus-menerus maka hasil belajar siswa akan menurun dan sulit untuk dirubah. Untuk mengatasi hal tersebut, salah 
satunya adalah memilih metode atau model pembelajaran yang tepat. Karena proses belajar mengajar merupakan suatu proses yang memerlukan perhatian khusus, keuletan, ketekunan, dan kerajinan. Oleh karena itu agar proses belajar mengajar yang sedang berlangsung berhasil dan berdaya guna secara efektif, maka proses belajar mengajar tersebut benar-benar akan semakin baik. Dalam hal ini guru dituntut untuk dapat memilih secara selektif metode atau model pembelajaran mana yang dapat digunakan dan sesuai dengan tujuan, bahan materi, alat bantu, dan evaluasi yang ditetapkan, karena keberhasilan proses belajar mengajar dipengaruhi banyak faktor, diantaranya pemilihan metode mengajar, minat siswa terhadap materi yang diajarkan dan peran guru dalam mengatasi kesulitan belajar.

Model pembelajaran, mempunyai peran strategis dalam upaya mendongkrak keberhasilan proses belajar mengajar. Karena ia bergerak dengan melihat kondisi kebutuhan siswa, sehingga guru diharapkan mampu menyampaikan materi dengan tepat tanpa mengakibatkan siswa mengalami kebosanan. Namun sebaliknya, siswa diharapkan dapat tertarik dan terus mengikuti pelajaran, dengan keingintahuan yang berkelanjutan.

Solusi penyelesaian untuk mengatasi permasalahan $\mathrm{di}$ atas dapat dilakukan dengan penggunaan model pembelajaran yang bersifat inkuiri ilmiah dan konstruktivis dalam pembelajaran. Salah satu model pembelajaran yang dimaksud adalah Learning Cycle 7E. Model siklus belajar adalah model pembelajaran yang berpusat pada siswa. ${ }^{[1]}$ Pembelajaran sains berbasis kontruktivisme dan metode pengajarannya berpusat pada siswa adalah learning cycle (siklus belajar). Ada banyak macam model pembelajaran bersiklus, dalam kurikulum 2013 dikenalkan siklus pembelajaran 5M (Mengamati, Menanya, Mencoba, Mengasosiasi, dan
Mengkomunikasikan), ada juga siklus belajar 5E dan siklus belajar 7E.

Model pembelajaran Learning Cycle $7 E$ merupakan model pembelajaran yang memberikan kesempatan kepada siswa untuk membangun pengetahuannya sendiri berdasarkan pada pengetahuan awal yang dimiliki. Model pembelajaran ini merupakan pendekatan yang ampuh untuk perancangan pembelajaran IPA yang aktif dan efektif karena memberikan suatu cara berfikir dan berperilaku yang konsisten dengan cara siswa belajar.

Model pembelajaran Learning Cycle $7 E$ berpengaruh positif terhadap hasil belajar fisika siswa. ${ }^{[3]}$ Penerapan model Learning Cycle $7 E$ berpengaruh positif terhadap hasil belajar kognitif, afektif dan psikomotorik siswa. Model pembelajaran Learning Cycle $7 E$ adalah model siklus belajar yang melibatkan siswa secara aktif melalui 7 fase dalam pembelajaran, yaitu elicite, engange, explore, explain, elaborate, evaluate, dan extend. Hal ini berdasarkan penelitian Eeisenkraft yang mengatakan bahwa model $7 \mathrm{E}$ mengembangkan 5 tahapan dari model 5E menjadi 7E tahapan yaitu elicit, engange, explore, explain, elaborate, evaluate, dan extend.

Dengan cara ini, siswa dapat lebih mudah memahami pelajaran fisika, khususnya materi fluida stastis. Pada materi fluida statis apabila siswa hanya diberikan penjelasan saja maka siswa akan sedikit kebingungan dengan konsep fluida statis dan penerapannya dalam kehidupan sehari-hari. Dengan model Learning Cycle $7 E$ diharapkan dapat memudahkan siswa dalam memahami konsep fluida statis dan dapat meningkatkan hasil belajar siswa.

Sesuai dengan permasalahan di atas, penelitian ini bertujuan untuk mengetahui pengaruh model learning cycle $7 E$ terhadap hasil belajar fisika siswa kelas XI SMAN 8 Mataram. Penelitian ini diharapkan mampu memberikan pengaruh positif terhadap 
pembelajaran fisika, serta dapat bermanfaat untuk siswa, sekolah, guru dan peneliti selanjutnya yang akan meneliti tentang model yang sama.

\section{TINJAUAN PUSTAKA}

\section{a. Learning Cycle $7 E$}

Model pembelajaran sains berbasis kontruktivisme dan metode pengajarannya berpusat pada siswa adalah learning cycle (siklus belajar). Ada banyak macam model pembelajaran bersiklus, dalam kurikulum 2013 dikenalkan siklus pembelajaran 5M (Mengamati, Menanya, Mencoba, Mengasosiasi, dan Mengkomunikasikan), ada juga siklus belajar 5E dan siklus belajar 7E. Model pembelajaran Learning Cycle 7E adalah model siklus belajar yang melibatkan siswa secara aktif melalui 7 fase dalam pembelajaran, yaitu elicite, engange, explore, explain, elaborate, evaluate, dan extend.

Keuntungan model pembelajaran Learning Cycle yaitu: 1) meningkatkan motivasi belajar karena siswa dilibatkan secara aktif dalam proses pembelajaran, 2) membantu mengambangkan sikap ilmiah siswa dan 3) pembelajaran lebih bermakna. Model pembelajaran Learning Cycle baik diterapkan karena: 1) membuat guru mengetahui pengetahuan awal yang dimiliki siswa sebelum memulai pembelajaran, 2) mengembangkan pembelajaran yang kooperatif dengan suasana belajar yang positif, 3) terjadi kombinasi atau integrasi pengetahuan baru yang diterima siswa dengan pengetahuan awal yang dimiliki siswa, 4) siswa dapat membangun pengetahuaanya sendiri 5) siswa dapat mengaplikasikan pengetahuan baru dengan cara yang berbeda dari situasi yang telah dipelajari siswa.

Berdasarkan keuntungan penggunaan model learning cycle di atas, dapat diketahui bahwa selain mengembangkan sikap ilmiah siswa, model ini juga bisa meningkatkan motivasi serta aktifitas siswa dalam proses pembelajaran sehingga siswa akan lebih mudah memahami materi yang sedang dibahas dan prestasi belajar fisika siswapun meningkat. ${ }^{[4]}$ Model pembelajaran learning cycle $7 E$ adalah salah satu model pembelajaran yang menganut teori konstruktivisme. Secara filosofis, belajar menurut teori konstruktivisme adalah membangun pengetahuan sedikit demi sedikit, yang kemudian hasilnya diperluas melalui konteks yang terbatas dan tidak sekonyong konyong.

Tahapan-tahapan model pembelajaran learning cycle $7 E$ dapat dijelaskan sebagai berikut:

1. Elicit (mendatangkan pengetahuan awal siswa), yaitu fase untuk mengetahui sampai dimana pengetahuan awal siswa yang berhubungan dengan materi yang akan dipelajari.

2. Engage (membangkitkan minat), pada tahap ini guru berusaha membangkitkan minat siswa tentang topik yang akan diajarkan.

3. Explore (mengeksplor), pada tahap ini dibentuk kelompok-kelompok kecil, kemudian diberi kesempatan untuk bekerja sama dalam kelompok kecil tanpa pembelajaran langsung dari guru. Siswa didorong untuk bekerja sama dalam kelompok untuk menguji hipotesis dan atau membuat hipotesis baru, mencoba alternatif pemecahannya dengan teman sekelompok, melakukan dan mencatat pengamatan serta ide-ide atau pendapat yang berkembang dalam diskusi. Guru berperan sebagai fasilitator dan motivator.

4. Explain (menjelaskan), pada tahap ini guru membimbing siswa untuk menjelaskan hasil eksplorasi mereka. Pada tahap ini guru dituntut mendorong siswa untuk menjelaskan suatu konsep dengan kalimat/pemikiran sendiri, 
meminta bukti dan klarifikasi atas penjelasan siswa, dan saling mendengar secara kritis penjelasan antarsiswa dan guru.

5. Elaborate (menerapkan), tahap ini memberikan kesempatan bagi siswa untuk menerapkan pengetahuan mereka. Fase ini guru memberikan pertanyaan yang lebih rumit (sulit) untuk membuat siswa menerapkan pengetahuan yang telah diperoleh.

6. Extend (memperluas), pada fase extend pengetahuan diterapkan dalam konteks yang baru dan tidak terbatas pada elaborate. Fase ini dapat dilakukan dengan mengaitkan konsep yang dipelajari dengan konsep yang lain.

7. Evaluate (mengevaluasi), pada tahap evaluasi guru mengevaluasi hasil belajar siswa.

\section{b. Hasil belajar}

Hasil belajar dapat dijelaskan dengan memahami dua kata yang membentuknya, yaitu "hasil" dan "belajar". Pengertian hasil mengarah pada suatu perolehan akibat dilakukannya suatu aktivitas atau proses yang mengakibatkan berubahnya input secara fungsional ${ }^{[6]}$. Belajar dilakukan untuk mengusahakan adanya perubahan perilaku pada individu yang belajar. Perubahan perilaku merupakan perolehan yang menjadi hasil belajar. Hasil belajar perlu dievaluasi. Evaluasi dimaksudkan sebagai cermin untuk melihat kembali apakah tujuan yang ditetapkan telah tercapai dan apakah proses belajar mengajar telah berlangsung efektif untuk memperoleh hasil ${ }^{[7]}$. ${ }^{[8]}$ Hasil belajar merupakan sebuah tindakan evaluasi yang dapat mengungkap aspek proses berpikir (cognitive domain) juga dapat mengungkap aspek kejiwaan lainnya, yaitu aspek keterampilan (affective domain) dan aspek keterampilan (psychomotor domain) yang melekat pada diri setiap individu peserta didik.
Hasil belajar adalah hasil yang diperoleh peserta didik setelah dilakukan aktifitas belajar. Hasil belajar terdiri dari kognitif, afektif dan psikomotor ${ }^{[9]}$. Menurut bloom, hasil belajar mencakup kemampuan kognitif, afektif, dan psikomotorik. Domain kognitif mencakup knowledge (pengetahuan, ingatan), comprehension (pemahaman, menjelaskan, meringkas, contoh), application (menerapkan), analysis (menguraikan, menentukan hubungan), synthesis (mengorganisasikan, merencanakan, membentuk bangunan baru), dan evaluation (menilai). Domain afektif mencakup receiving (sikap menerima), responding (memberikan respon), valuing (nilai), organization (organisasi), dan characterization (karakterisasi). Domain psikomotor meliputi initiatory, pre-routine, dan rountinized.

\section{METODE PENELITIAN}

Jenis penelitian yang digunakan adalah eksperimen. Penelitian eksperimen meneliti ada tidaknya hubungan sebab akibat dan berapa besar hubungan sebab akibat tersebut dengan cara memberi perlakuan tertentu pada beberapa kelompok eksperimen dan menyediakan kontrol sebagai perbandingan. Penelitian ini dilaksanakan dari bulan Maret 2017 sampai bulan Oktober 2017 bertempat di SMAN 8 Mataram. Penelitian ini difokuskan pada tiga variabel, yaitu variabel bebas, variabel terikat dan variabel kontrol. Variabel bebas pada penelitian ini adalah Learning cycle 7e, variabel terkatnya adalah hasil belajar dan variabel kontrolnya adalah guru, materi pembelajaran, tujuan pembelajaran, silabus, RPP, LKPD, dan jumlah jam pelajaran. Desain penelitian ini adalah pretest-posttest group design. Populasi dalam penelitian ini adalah seluruh siswa kelas XI MIA. Teknik pengambilan sampel yang digunakan adalah purposive sampling.melalui teknik ini didapatkan kelas XI MIA 1 sebagai kelas eksperimen yang 
diberikan perlakuan dengan model learning cycle 7e dan kelas XI MIA 2 sebagai kelas kontrol yang diberikan perlakuan sebagai model konvensional.

Prosedur kegiatan penelitian ini dilakukan dalam tiga tahap, yaitu

1. Tahap Persiapan

Pada tahap persiapan, peneliti mempersiapkan segala sesuatu yang dibutuhkan sebelum melaksanakan penelitian yaitu sebagai berikut: a. Studi literatur atau pustaka, mengenai metodologi yang digunakan, pembelajaran, maupun materi pokok bahasan yang diajarkan menggunakan model learning cycle $7 E$, serta mencari berbagai macam teori tentang penelitian yang dilakukan, b. Menentukan sekolah yang dijadikan tempat penelitian yaitu SMAN 8 Mataram, c. Melakukan observasi pembelajaran di kelas yang dilakukan untuk mengetahui kondisi kelas, kondisi siswa dan pembelajaran yang biasa dilaksanakan yaitu XI Mia, d. Telaah kurikulum sekolah untuk menentukan materi pokok yang diajarkan dengan model learning cycle $7 E$, dan e. Menyusun proposal penelitian, silabus, rencana pelaksanaan pembelajaran (RPP) dan instrumen penelitian.

\section{Tahap Pelaksanaan}

Langkah-langkah yang ditempuh pada saat pelaksanaan penelitian adalah sebagai berikut: a. Melakukan uji coba instrumen di SMAN 8 Mataram dengan kelas yang berbeda yang sudah mempelajari materi fluida statis, b. Menganalisis hasil uji coba instrumen yang meliputi validitas soal, reabilitas butir soal, tingkat kesukaran dan daya beda, c. Menentukan sampel penelitian yang terdiri dari dua kelas yakni kelas eksperimen dan kelas control, d. Melakukan tes awal hasil belajar kepada kelompok eksperimen dan kelompok kontrol, kemudian menguji homogenitas dan normalitas kedua sampel, e.Memberikan perlakuan lanjutan pada kelas eksperimen yakni menggunakan model model Learning Cycle 7E, f. Memberikan perlakuan pada kelas kontrol berupa pembelajaran konvensional, dan g. Memberikan tes akhir hasil belajar yang telah diuji sebelumnya pada kedua kelompok sampel yang dipilih.

3. Tahap Akhir

Langkah-langkah yang ditempuh sebagai tahap akhir penelitian ini adalah sebagai berikut: a. Menganalisis data hasil tes awal dan tes akhir yang diberikan kepada siswa, b. Menyimpulkan data hasil penelitian dan c. Membuat laporan hasil penelitian.

Teknik pengambilan data pada penelitian ini adalah tes hasil belajar. Tes adalah suatu alat ukur atau prosedur yang sistematis dan objektif untuk memperoleh data atau keterangan yag diinginkan tentang seseorang dengan cara yang tepat dan cepat. Data tes awal dan tes akhir diperoleh dengan menggunakan instrumen yang telah diujicobakan kepada siswa kelas XII MIA yang sudah menerima materi fluida statis, kemudian hasil tes tersebut diukur uji validitas menggunakan product moment, uji reliabelitas soal menggunakan SpermanBrown, indeks kesukaran soal untuk tingkat kesukaran, dan indeks diskriminasi untuk daya beda soal. Berdasarkan hasil uji coba 30 butir soal terdapat 25 soal yang diterima dna digunakan untuk tes awal dan tes akhir. Analisis data tes akhir menggunakan uji t dua pihak (polled varians), yang sebelumnya sudah diuji homogenitas menggunakan uji-F dan uji normalitas menggunakan ChiKuadrat.

\section{HASIL DAN PEMBAHASAN}

Penelitian ini dilaksanakan selama 3 minggu di SMAN 8 Mataram. Peneitian ini mengukur ranah kognitif siswa yaitu dari C1 sampai C6. Tes yang digunakan untuk mengukur ranah kognitif adalah tes pilihan ganda dengan jumlah soal 25 butir. Adapun kemampuan kognitif siswa sebelum diberikan perlakuan terlihat dari skor tes 
awalnya (pre-test). Hasil kemampuan awal siswa kelas eksperimen dan kelsa kontrol disajikan dalam tabel 1 .

Tes awal diberikan untuk mengetahui homogenitas dan normalitas kemampuan awal siswa pada kelas kontrol dan kelas eksperimen. Pada saat melakukan tes awal, kelas eksperimen berjumlah 23 orang, sedangkan kelas kontrol berjumlah 24 orang. Berdasarkan hasil tes awal, diperoleh data bahwa nilai tertinggi pada kelas eksperimen dan kelas kontrol berturut-turut adalah 36 dan 40. Sedangkan nilai terendahnya sama yaitu 20. Nilai rata-rata pada kelas eksperimen adalah 26,783, sedangkan pada kelas kontrol adalah 28,333.Adapun secara grafik data nilai pretest siswa ditunjukkan pada gambar 1 .

Hasil tes awal digunakan untuk mengetahui homogenitas dan normalitas kemampuan awal kelas kontrol dan kelas eksperimen, maka dilakukan uji homogenitas dan uji normalitas.

Berdasarkan hasil pengelolahan data didapatkan $F_{\text {hitung }}<F_{\text {tabel }}$ pada taraf signifikan $5 \%$. Hal ini berarti kedua kelas homogen, atau siswa pada kedua kelas memiliki kemampuan awal yang sama, serta $\chi_{\text {hitung }}^{2}<\chi_{\text {tabel }}^{2}$ baik pada kelas eksperimen maupun kelas kontrol. Hal ini menunjukkan bahwa data awal hasil belajar fisika siswa pada keduan terdistribusi normal.

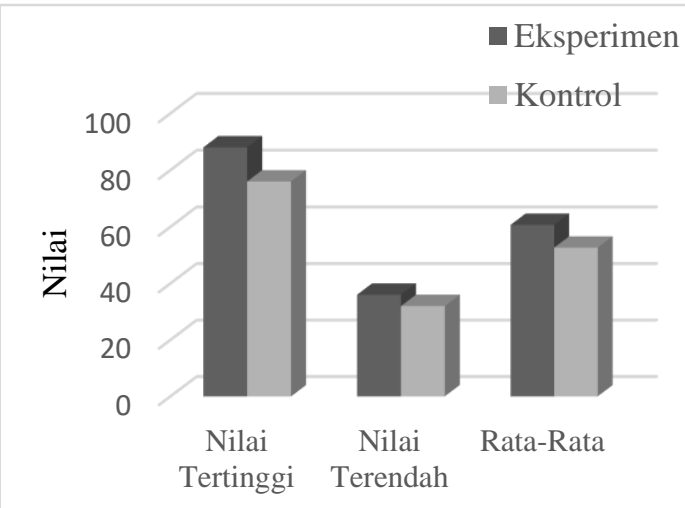

Gambar 1. Data Hasil Tes Awal Siswa Kelas Eksperimen dan Kelas Kontrol
Tes akhir diberikan untuk mengetahui homogenitas dan normalitas kemampuan akhir siswa pada kelas kontrol dan kelas eksperimen. Pada saat melakukan tes akhir, kelas eksperimen berjumlah 23 orang, sedangkan kelas kontrol berjumlah 24 orang. Berdasarkan hasil tes akhir, diperoleh data bahwa nilai tertinggi pada kelas eksperimen dan kelas kontrol berturut-turut adalah 88 dan 76. Sedangkan nilai terendahnya sama yaitu 20. Nilai rata-rata pada kelas eksperimen adalah 60,696 sedangkan pada kelas kontrol adalah 52,667.

Adapun secara grafik data nilai posttest siswa ditunjukkan pada gambar 2 berikut:

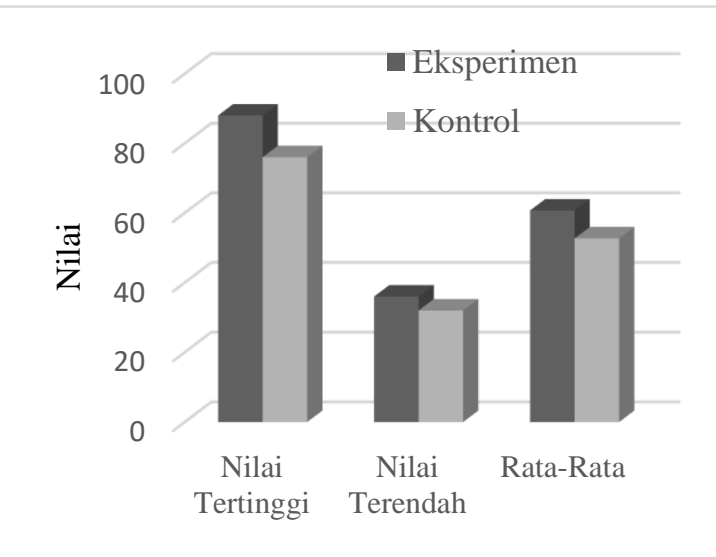

Gambar 2. Tes Akhir Siswa Kelas Eksperimen dan Kelas Kontrol

Hasil tes akhir digunakan untuk mengetahui homogenitas dan normalitas kemampuan akhir kelas kontrol dan kelas eksperimen, maka dilakukan uji homogenitas dan uji normalitas. Berdasarkan data yag didapatkan $F_{\text {hitung }}<$ $F_{\text {tabel }}$ pada taraf signifikan $5 \%$. Hal ini berarti kedua kelas homogen, atau siswa pada kedua kelas memiliki kemampuan awal yang sama. Serta $\chi_{\text {hitung }}^{2}<\chi_{\text {tabel }}^{2}$ baik pada kelas eksperimen maupun kelas kontrol. Hal ini menunjukkan bahwa data awal hasil belajar fisika siswa pada keduan terdistribusi normal.

Dalam penelitian ini, uji hipotesis dilakukan untuk mengetahui pengaruh 
perlakuan yang diberikan terhadap hasil belajar. Setelah melakukan uji homogenitas dan uji normalitas sampel dari data hasil belajar posttest, diperoleh bahwa siswa berasal dari populasi yang berdistribusi normal dan memiliki varians yang homogen sehingga uji hipotesis yang digunakan adalah uji statistik parametrik. Adapun uji statistik parametrik yang digunakan dalam penelitian ini adalah uji-t satu pihak dengan menggunakan rumus t-test polled varians dan dibantu dengan program Ms. Excel 2010. Hasil analisis uji hipotesis data terhadap hasil belajar fisika siswa dapat dilihat pada tabel 1 .

Tabel 1. Analisis Hipotesis Posttest

\begin{tabular}{ccc}
\hline Kelas & Eksperimen & Kontrol \\
\hline $\mathrm{N}$ & 23 & 24 \\
$\bar{x}$ & 60,696 & 52,667 \\
$S$ & 13,573 & 13,011 \\
$S^{2}$ & 173,846 & 169,275 \\
$t_{\text {hitung }}$ & 2,071 & \\
$t_{\text {tabel }}$ & 1,679 & \\
\hline
\end{tabular}

Nilai tabel untuk uji dua pihak dengan $\mathrm{dk}=$ $23+24-2=45$ pada taraf signifikan 0,05 adalah 1,679. Sehingga $t_{\text {hitung }}>t_{\text {tabel }}$ yaitu $2,071>1,679$; yang berarti bahwa $\mathrm{H}_{\mathrm{o}}$ ditolak $\left(\mathrm{H}_{\mathrm{o}}=\right.$ tidak terdapat pengaruh model Learning Cycle $7 E$ terhadap hasil belajar fisika siswa kelas XI SMAN 8 Mataram). Karena $t_{\text {hitung }}$ lebih besar dari $t_{\text {tabel }}$, maka dapat disimpulkan bahwa terdapat pengaruh model learning cycle $7 e$ terhadap hasil belajar fisika siswa kelas XI SMAN 8 Mataram.

\section{Data Hasil Belajar Ranah Afektif dan Psikomotorik}

a. Ranah Afektif

Adapun data afektif yang diperoleh dari hasil observasi untuk kelas eksperimen dan kelas kontrol adalah
Tabel 2. Data Hasil Observasi Ranah Afektif Kelas Eksperimen

\begin{tabular}{lll}
\hline Ranah Afektif & Persentase & Kategori \\
\hline rasa ingin tahu & 72,174 & Baik \\
kerja sama & 60,870 & Cukup \\
Jujur & 73,913 & Cukup \\
Kritis & 60,000 & Cukup \\
Kagum & 70,435 & Baik \\
\hline
\end{tabular}

Tabel di atas adalah hasil observasi ranah afektif. Berdasarkan observasi didapatkan bahwa ranah afektif kelas eksperimen lebih tinggi dibandingkan kelas kontrol. Berikut tabel ranah afektif kelas kontrol:

Tabel 3. Data Hasil Observasi Ranah Afektif Kelas Kontrol

\begin{tabular}{lll}
\hline Ranah Afektif & Presentasi & Kategori \\
\hline rasa ingin tahu & 65,000 & Cukup \\
kerja sama & 60,833 & Cukup \\
Jujur & 65,833 & Cukup \\
Kritis & 60,000 & Cukup \\
Kagum & 70,000 & Baik \\
\hline
\end{tabular}

Berdasarkan tabel di atas dapat dilihat bahwa terdapat perbedaan antara kelas kontrol dan kelas eksperimen pada ranah afektif. dimana ranah afektif kelas eksperimen lebih tinggi dibandingkan kelas kontrol.

\section{b. Ranah Psikomotorik}

Adapun data psikomototor yang diperoleh dari hasil observasi untuk kelas eksperimen dan kelas kontrol adalah

Tabel 4. Data Hasil Observasi Ranah Psikomotor Kelas Eksperimen

\begin{tabular}{lll}
\hline Ranah Psikomotorik & Presentase & Kategori \\
\hline $\begin{array}{l}\text { Mempersiapkan Alat } \\
\text { dan Bahan }\end{array}$ & 75,652 & Baik \\
$\begin{array}{l}\text { Keterampilan } \\
\text { Merangkai Alat dan }\end{array}$ & 62,609 & cukup \\
$\begin{array}{l}\text { Bahan } \\
\text { Keterampilan dalam }\end{array}$ & & \\
$\begin{array}{l}\text { Melaksanakan } \\
\text { Percobaan }\end{array}$ & 71,304 & Baik \\
$\begin{array}{l}\text { Kesungguhan dalam } \\
\text { Mengamati }\end{array}$ & 66,956 & Cukup \\
Percobaan & & \\
\hline
\end{tabular}




\begin{tabular}{|c|c|c|}
\hline Ranah Psikomotorik & Presentase & Kategori \\
\hline Keterampilan dan & & \\
\hline $\begin{array}{l}\text { Kebersihan } \\
\text { Praktikum }\end{array}$ & 71,304 & Baik \\
\hline
\end{tabular}

Tabel di atas adalah hasil observasi ranah psikomotor. Berdasarkan observasi didapatkan bahwa ranah psikomotor kelas eksperimen lebih tinggi dibandingkan kelas kontrol. Berikut tabel ranah psikomotor kelas kontrol.

Tabel 5. Data Hasil Observasi Ranah

\begin{tabular}{lll}
\multicolumn{3}{c}{ Psikomotor Kelas Kontrol } \\
\hline $\begin{array}{l}\text { Ranah } \\
\text { Psikomotorik }\end{array}$ & Presentase & Kategori \\
\hline $\begin{array}{l}\text { Mempersiapkan } \\
\text { Alat dan Bahan }\end{array}$ & 60 & cukup \\
$\begin{array}{l}\text { Keterampilan } \\
\text { Merangkai Alat }\end{array}$ & 61,667 & cukup \\
dan Bahan & & \\
$\begin{array}{l}\text { Keterampilan } \\
\text { dalam }\end{array}$ & 70 & baik \\
$\begin{array}{l}\text { Melaksanakan } \\
\text { Percobaan }\end{array}$ & & \\
$\begin{array}{l}\text { Kesungguhan } \\
\text { dalam Mengamati }\end{array}$ & 69,167 & cukup \\
$\begin{array}{l}\text { Percobaan } \\
\text { Keterampilan dan }\end{array}$ & & \\
$\begin{array}{l}\text { Kebersihan Alat } \\
\text { Praktikum }\end{array}$ & 70,833 & baik \\
\hline
\end{tabular}

Berdasarkan tabel di atas dapat dilihat bahwa terdapat perbedaan antara kelas kontrol dan kelas eksperimen pada ranah psikomotor. dimana ranah psikomotor kelas eksperimen lebih tinggi dibandingkan kelas kontrol.

Model pembelajaran Learning Cycle $7 E$ yang diterapkan pada kelas eksperimen memiliki keunggulan yaitu, meningkatkan motivasi belajar karena siswa dilibatkan secara aktif dalam proses pembelajaran, mengambangkan sikap ilmiah siswa dan pembelajaran lebih bermakna. Selain itu, model pembelajaran Learning Cycle $7 E$ baik diterapkan karena, membuat guru mengetahui pengetahuan awal yang dimiliki siswa sebelum memulai pembelajaran, mengembangkan pembelajaran yang kooperatif dengan suasana belajar yang positif, terjadi kombinasi atau integrasi pengetahuan baru yang diterima siswa dengan pengetahuan awal yang dimiliki siswa, siswa dapat mengaplikasikan pengetahuan baru dengan cara yang berbeda dari situasi yang telah dipelajari siswa.

Model pembelajaran konvensional dengan metode percobaan yang diterapkan pada kelas kontrol adalah metode belajar yang cara penyajiannya dihadapkan hanya kepada suatu masalah yang bisa berupa pernyataan atau pertanyaan yang bersifat problematis untuk dibahas dan dipecahkan bersama. Proses pembelajaran di dalamnya siswa hanya melakukan percobaan tanpa ada proses pengaplikasian percobaan yang dilakukan dalam kehidupan sehari-hari. Hal ini membuat siswa kurang berperan secara aktif dan antusias belajar siswa rendah, sehingga dapat mempengaruhi hasil belajar siswa menjadi rendah pula.

Bedasarkan hasil analisis data awal siswa didapatkan nilai rata-rata kelas eksperimen dan kelas kontrol masingmasing 26,783 dan 28,333. Dari data awal kelas eksperimen dan kelas kontrol diketahui bahwa kedua kelas tedistribusi normal dan homogen. Sedangkan untuk data akhir siswa didapatkan nilai rata-rata kelas eksperimen dan kelas kontrol masing-masing 60,696 dan 52,667. Data akhir siswa kelas ekperimen dan kelas kontrol terdistribusi normal dan homogen.

Data hasil posttest menunjukkan terdapat perbedaan rata-rata hasil belajar siswa kelas eksperimen dengan kelas kontrol. Terlihat hasil posttest kelas eksperimen lebih tinggi dibandingkan kelas kontrol. Peningkatan nilai rata-rata dapat menjadi tolak ukur tingkat keberhasilan dalam pencapaian hasil belajar. Hasil uji hipotesis posttest menunjukkan bahwa $t_{\text {hitung }}=2,071$ sedangkan untuk $t_{\text {tabel }}=$ 1,679 itu artinya $t_{\text {hitung }}>t_{\text {tabel }}$. Maka 
berdasarkan kriteria pengujian hipotesis $\mathrm{H}_{\mathrm{o}}$ ditolak dan $\mathrm{H}_{\mathrm{a}}$ ditolak, artinya bahwa terdapat pengaruh pemberian model Learning Cycle $7 E$ terhadap hasil belajar fisika siswa kelas XI SMAN 8 Mataram.

Selain hasil belajar ranah kognitif, hasil belajar ranah afektif dan psikomotor siswa juga diukur berdasarkan observasi peneliti. Kelas eksperimen memiliki hasil belajar ranah afektif dan psikomotor yang cukup tinggi dibandingkan dengan kelas kontrol. Hasil belajar ranah afektif dan psikomotor memiliki pengaruh yang cukup besar pada hasil belajar siswa ranah kognitif, hal tersebut terlihat dari pencapaian rata-rata hasil akhir siswa kelas eksperimen dan kontrol.

Temuan dalam penelitian ini diperkuat beberapa penelitian sebelumnya diantaranya adalah Simatupang (2008) menyatakan bahwa penggunaan model pembelajaran learning cycle 7E dapat mempermudah belajar siswa karena mereka secara langsung berinteraksi dengan lingkungan untuk menganalisis fenomenafenomena perilaku sosial sehingga mereka dapat memahami konsep-konsep materi ajar sehingga tujuan pengajaran dapat tercapai. Siribunnam dan Tayraukham (2009) menyatakan bahwa siswa yang belajar dengan menggunakan model pembelajaran learning cycle 7E memperoleh hasil belajar yang lebih tinggi daripada belajar menggunakan pembelajaran konvensional.

\section{PENUTUP}

Berdasarkan hasil penelitian dan pembahasan, maka dapat ditarik kesimpulan bahwa terdapat pengaruh model Learning Cycle $7 E$ terhadap hasil belajar IPA Terapan siswa kelas XI SMAN 8 Mataram. Kelas eksperimen menggunakan model learning cycle $7 \mathrm{e}$ menunjukkan peningkatan hasil belajar lebih tinggi dibandingkan kelas kontrol dengan menggunakan model pembelajaran konvensional. Adapun saransaran yang dapat diberikan bagi siswa, dengan penelitian ini siswa diharapkan dapat meningkatkan hasil belajar dan mampu mengaplikasikan fisika dengan lingkungan masing-masing. Bagi guru, sebagai referensi bahwa model pembelajaran Learning Cycle $7 e$ dapat membantu siswa untuk lebih mudah dalam memahami pelajaran. Bagi pembaca, penelitian ini dapat dijadikan sebagai referensi dan perbandingan jika pembaca ingin melakukan penelitian yang sejalan sehingga dapat memperkuat hasil penelitian ini. Bagi peneliti, hasil penelitian ini diharapkan sebagai penguat pemahaman terkait model pembelajaran.

\section{REFERENSI}

Apriani, D., Sujana, A., dan, Kurnia, D. 2016. Penerapan model pembelajaran learning cycle pada materi perubahan sifat benda untuk meningkatkan hasil belajar siswa. Jurnal Pena Ilmiah. 1(1): 781790.

Eisenkraft, A. 2003. Expanding the 5E Model a proposed 7E Model. Emphasizes a Journal for High School Science Educators Published by The National Science Teachers Association the Science Teacher. 70(6): 56.

Handriani, S. H., harjono, A., doyan, A. 2015. Model pembelajaran inkuiri terstruktur dengan pendekatan saintifik terhadap kemampuan berpikir kritis dan hasil belajar fisika siswa. Jurnal Pendidikan Fisika Dan Teknologi (JPFT). 3(1): 213.

Imaniyah, I., Siswoyob, Bakric, F. 2015. Pengaruh Model Pembelajaran Learning Cycle 7e Terhadap Hasil Belajar Fisika Siswa SMA. Jurnal Penelitian dan Pengembangan Pendidikan Fisika. 1(1). 18.

Jiniarti, B.E., Sahidu. C., Verawati. S.P. 2015. Implementasi Model Problem Based Learning Berbantuan Alat 
Peraga Untuk Meninhkatkan Aktivitas Dan Hasil Belajar Fisika Siswa Kelas VIII SMPN 22 Mataram Tahun Ajaran 2014/2015. Jurnal Pendidikan Fisika Dan Teknologi (JPFT). 3(1): 188.

Laelasari, Toto, S., dan Nurul, I.K. 2015. Penerapan model pembelajaran learning cycle 7e dalam kemampuan representasi matematis siswa. Jurnal Euclid. 1(2):82-92.

Muammar, H., Hardjono, A., Gunawan. 2015. Pengaruh Model Pembelajaran Assure Dan Pengetahuan Awal Terhadap Hasil Belajar Ipa-Fisika Siswa Kelas VIII SMPN 22 Mataram. Jurnal Pendidikan Fisika Dan Teknologi (JPFT). 3(1): 167.

Sahidu, C. 2013. Penilaian Hasil Belajar. Mataram: Arga Puji Press.

Simatupang, D. 2008. Pembelajaran Model Siklus Belajar (Learning Cycle). Jurnal Kewarganegaraan. 10 (1): $62-70$.

Siribunnam, \& Tayraukham. 2009. Effect of 7-E, KWL, and Conventional Instruction on Analytical Thingking, Learning Achievement and attitudes toward Chemistry Learning. Journal of Social Science. 5 (4): 279-282.

Sugiyono. 2012. Statistika Untuk Penelitian. Bandung : Alfabeta. 